\title{
Childcare for Children under Three Years of Age from Mothers' Point of View within the International Context
}

\author{
Lucie Grůzová, Zora Syslová
}

\begin{abstract}
The present study brings a discussion on institutional care and education for children under three into the professional discourse. In the introduction, the authors introduce the historical context of care for children under the age of three in the Czech Republic and compare it with the situation elsewhere in the European Union. The core of the article was mothers' viewpoint on facilities for children under three in the Czech Republic. A qualitative probe answers the question, "How do mothers perceive facilities for children under three years of age?" In-depth interviews revealed that the mothers who were addressed have a wide range of motives for deciding to place a child under three years of age in institutional care. Ultimately, however, they seek to satisfy the needs of their child. The situation of the sample that was monitored is in many respects comparable to foreign studies, even though the Czech situation regarding these services has specific features because of its historical development.
\end{abstract}

Keywords: early childhood education, day care institutions in the Czech Republic, state family policy, mothers

\section{INTRODUCTION}

Discussions on the quality of preschool education and the involvement of children under the age of three in this system are currently increasing. On the international scene, it is usually referred to as early education and care, meaning education and care for children from birth until their entry to compulsory primary education. The Czech Republic has its own specific history in this respect, as the beginnings of care for children under the age of three in this country date back to the end of the $19^{\text {th }}$ century. In the second half of the 20th century, the services offered to these children flourished, as the Czech Republic had an extensive network of kindergartens subsidized by the state budget and a curriculum elaborated in detail for children from birth until entry into primary education. After the revolution within the education reform, the care of children under three was pushed into the private sphere, and in recent years it has been difficult to build a new system 
of services that would match European standards in terms of its quality.

At present, there are about one hundred and forty thousand children under the age of three in Czech kindergartens and another eighteen thousand children are in private facilities in informal care (MLSA, 2019). At present, there are approximately 900 children's groups in the Czech Republic caring for 11,800 children aged between one and six (MLSA, 2019). Most of these children's groups have appeared in the last three years and are funded by maternal allowances and European Union grants, which will end in 2023. The Ministry of Labour and Social Affairs is preparing a bill on setting a maximum maternal allowance and state subsidies for these facilities, which would, for the first time since 1989, introduce direct state involvement in the care of children under the age of three.

The current situation regarding the care of children under the age of three became the main topic for the project Education and Early Childhood Care in Childcare Institutions in the Czech Republic (TL02000306), the aim of which was to map and document the experiences of key actors in various care facilities for children under the age of three (children, mothers, employees, management). Within the project, this research study came about, the aim of which is find out more about the situation with regard to care for children under the age of three within the context of the international concept of early childhood education and care from the point of view of some of the most important actors - the parents, or rather mothers.

\section{THE SITUATION ABROAD \\ REGARDING CARING \\ FOR CHILDREN UNDER}

THREE YEARS OF AGE

At the beginning of the $21^{\text {st }}$ century in the developed countries of the world, in the context of the growing employment of women, caring for the youngest children is a society-wide issue. These days, in the debate on whether to support family care for young children or to support participation in institutional care, the balance has clearly tipped towards providing support for institutional care. This view is based on many studies that show that early care brings great benefits, especially for at-risk children and the socially disadvantaged. Some studies show that the combination of the length of time a child attends a preschool facility (ideally from two years) and the high quality of a facility brings about the greatest effects of pre-school education at both the cognitive and socio-emotional levels (e.g. Sammons et al., 2008a, 2008b).

Since 2013, the EU's goal has been to provide quality institutional care for 33\% of the population under the age of three by 2030 (European Commission, 2013). This objective has already been met, for example, in Denmark, Sweden, the Netherlands, France, Spain, Portugal, Slovenia, Belgium, Luxembourg, and the United Kingdom (European Commission, 2016, p. 7). In contrast, countries such as the 
Czech Republic, Ireland, and Poland have almost no publicly funded services for children under the age of three. These countries are among the countries with extremely low use of these services. Currently, there is only one European country - Latvia - which guarantees free public education for every child from the age of one and a half. In the remaining countries, most mothers have to pay for ECEC (Early Childhood Education and Care) services. The average monthly fees are highest in Ireland, the Netherlands, the United Kingdom, and Switzerland.

"In order to establish a shared understanding of what this means, the Council adopted a Recommendation on HighQuality Early Childhood Education and Care Systems in May 2019 (European Commission, 2019, p. 9). ${ }^{1}$ Quality is monitored across European countries in five basic areas: governance, access, staff, and educational guidelines, as well as evaluation and monitoring (European Commission, 2019, p. 9). If the ECEC agenda is ensured by one ministry (e.g. the Nordic and Baltic countries, Ireland, Spain, Luxembourg, Malta, England, and Scotland) the quality is higher, as the main goals and principles, educational/pedagogical approaches, development and educational goals, areas of learning, content or materials, and assessment methods in the form of a state curriculum for the whole preschool period are clearly set out (European Commission, 2019, p. 96).
In addition to quality, the EU strives for member states to create integrated systems providing care and education for children from birth to primary education. Research shows that these systems provide children with better support for their holistic development (Kaga, Bennett, \& Moss, 2010). There is currently an integrated system in the Nordic countries (except Denmark), Latvia, and Slovenia. The second model, which is more widespread in Europe, is a differentiated system, where the services are divided up according to the age of the children (usually for children under the age of three and for children between the ages of three and six). The provision of services for these two age categories may fall within the competences of different ministries. In several countries (Denmark, Greece, Spain, Cyprus, and Lithuania), both models exist simultaneously.

In the Czech Republic, there is a significant difference between children's groups (under the Ministry of Social Affairs), facilities under the Trade Licensing Act (under the Ministry of Trade and Industry), and kindergartens (under the Ministry of Education). This difference is clearly reflected in the concept of the children's group, which sets out the care function of the facility, the number of children per carer, and hygiene standards. The state-given and controlled Framework Educational Programme for Preschool Education (2018) sets out the

${ }^{1}$ Council Recommendation of 22 May 2019 on High-Quality Early Childhood Education and Care Systems (OJ C 189, 5.6.2019, p. 4-14). 
main goals and principles, educational/ pedagogical approaches, development and educational goals, areas of learning, contents, and methods of assessment and evaluation.

One of the important quality criteria is the education of teachers or caregivers. Only one-third of European education systems require a Bachelor's degree or a higher qualification for working with children under the age of three (e.g. a Bachelor's degree in Bulgaria, Germany, Estonia, Greece, France, Croatia, Cyprus, Lithuania, Slovenia, Finland, Bosnia and Herzegovina, Montenegro, and Norway, a Master's degree in Portugal and Iceland) (European Commission, 2019, p. 71). In the Czech Republic, a basic level of education and completion of a course for carers for children until the beginning of compulsory school attendance is sufficient for caregivers working in children's groups.

Partnership with mothers is another of the important quality criteria (e.g. Sylva et al., 2004; Yoshikawa et al., 2013). Family support is essential if optimal conditions for children's learning and development are to be provided. The EU is therefore addressing the role of mothers in managing and evaluating the environment, as well as the support they receive when their children are in ECEC (European Commission, 2019, p. 25). Cooperation with the family is also part of the Czech concept of children's groups and one of the important areas of self-evaluation of kindergartens.

\section{AtTITUdes OF PARENTS TO CARE FOR CHILDREN UNDER THREE}

\section{YEARS OF AGE}

The availability and quality of childcare facilities for children under the age of three depends on the pro-family policy of each country. Using them then influences parents' attitudes towards this care and their return to the labour market. These attitudes are partly influenced by pro-family politics and are based on the economic situation of families, and the individual moral and ethical strategies of the family also have a significant influence. These strategies are often irrational, negotiated within families so as to be morally appropriate for maternal attitudes in combining parental and formal care and the economic situation of the family (see Duncan et al., 2004; Höhne \& Kuchařová, 2016; Kuchařová \& Nešporová, 2019). Gender culture and gender order have a significant influence on these strategies and on the social patterns of different social classes (where the education of the mother plays an important role) (cf. Del Boca, Pasqua, \& Pronzato, 2006, Hoem, 2005; Kameraman et al., 2003; Kucharova \& Nesporova, 2019; Neyer, 2003), and of different ethnic groups (cf. Duncan et al., 2004; Höhne \& Kuchařová, 2016).

According to research (e.g. Del Boca et al., 2006, p. 12) affordable day care for young children has a positive effect on women's participation in the labour market, although this depends on their education (it is especially true for more educated 
women). A study in the Czech Republic (Kuchařová et al., 2006a, 2006b, 2009) found similar results, stating that women with higher education use day care services more.

The differences in the attitudes of families in European Union countries are most affected by the length of maternity leave. Most countries support mothers returning to work as soon as possible (e.g. 1.8 months in Germany, Austria, and France; within 12 months in Poland and the United Kingdom) (European Commission, 2015). This situation is different in the Czech Republic. The length of maternity leave in the Czech Republic is one of the longest in the European Union. Mothers can choose to receive a maternal allowance for up to four years (Hašková, Mudrák, \& Saxonberg 2012; Kuchařová et al., 2009; Saxonberg, 2014). In Czech families with young children, the prevailing view is that children need to be provided with adequate home care and that young children suffer if their mother is employed (people with the lowest levels of education are more often in favour of this view) (Duncan et al., 2004; Höhne \& Kuchařová, 2016; Kampichler, Dvořáčková, \& Jarkovská, 2018; Kuchařová et al., 2006a, 2010).

Assistance from grandmothers is often chosen as one of the first care options for young children (Gray, 2005; Hamplová, 2014). However, with increasing life expectancy, fewer children in families, and the promotion of an active old age, this indicator is also changing and being replaced by informal care provided by acquaintances or friends (e.g. in postCommunist countries such as the Czech Republic, Slovakia, or Poland, but also the United Kingdom, Slovenia, and Italy) (Hašková \& Uhde, 2019, pp. 477, 492).

However, when parents decide to use an ECEC facility, they mainly pay attention to the following factors: opening hours, child-to-teacher ratio, accreditation, programme and environmental equipment, and child-centred factors (e.g. a programme adapted to the child's abilities, providing freedom to explore, and encouraging curiosity and choice) (Gamble, Ewing, \& Wilhelm, 2009, p. 79).

Another global phenomenon is parents' attitudes towards private and public institutions, which is linked to the problem of the reproduction of social inequalities, which the EU wants to combat. Unfortunately, the set-up of education systems and national policy measures help to reproduce these inequalities. It can be seen that mothers who put children in prestigious private kindergartens associate private educational institutions with an amplitude of resources and knowledge, while public institutions are perceived as places with shortcomings (Kampichler et al., 2018). The extent to which these maternal assessments are objective is often discussed as a risk of studies (e.g. Gamble et al., 2009).

\section{RESEARCH METHODOLOGY}

This research study is of a qualitative nature and maps the situation of maternal views on care facilities for children under 
three years of age in the context of two large cities (Brno, Ostrava) with a highly diversified range of early care and educational facilities. The research question was the following: "How do mothers perceive facilities for children under three years of age?" This research question was further specified in the partial research questions: (1) What are mothers' beliefs about facilities for children under three years of age? (2) What are mothers' expectations of these facilities? (3) What are mothers' reasons for searching for these facilities? (4) What is mothers' experience with these facilities?

In the first step, facilities providing care for children under three years of age were addressed so as to represent all the types of institutions that can be established in the Czech Republic under various ministries (children's groups, childcare under the Trade Licensing Act, kindergartens established under the Education Act). The selection of specific facilities was based on previous contacts with their management.
To understand the broader context, we attach the characteristics of the facilities (see Table 1), as in several respects they exceed the standards set by the state (e.g. in the education of their teachers).

In the second step, interviews were conducted with head teachers and teachers. We received recommendations for mothers from them. The research sample consisted of mothers with different experiences with early care and education and different levels of education from three different facilities: in Ostrava a children's group established at a kindergarten (funding body the Ministry of Education and Ministry of Labour and Social Affairs) (mothers 1-6), in Brno a children's centre established as a business for short-term care (funding body the Ministry of Social Affairs) (mothers 7-9), and a children's group established as a private non-profit organization in Brno (funding body the Ministry of Industry and Trade) (mothers 10-12) (see Table 2).

Table 1 Characteristics of the Facilities

\begin{tabular}{|l|l|l|l|l|}
\hline $\begin{array}{l}\text { Name of the } \\
\text { Facility }\end{array}$ & $\begin{array}{l}\text { Local } \\
\text { authority }\end{array}$ & $\begin{array}{l}\text { Capacity and } \\
\text { age of children }\end{array}$ & $\begin{array}{l}\text { Number of staff and their } \\
\text { education }\end{array}$ & $\begin{array}{l}\text { Monthly fees } \\
\text { for full-time } \\
\text { attendance }\end{array}$ \\
\hline $\begin{array}{l}\text { Kindergarten } \\
\text { with a childre- } \\
\text { n's group }\end{array}$ & $\begin{array}{l}\text { Ostrava } \\
\text { City }\end{array}$ & $\begin{array}{l}16 \text { children, } \\
2-3 \text { years }\end{array}$ & $\begin{array}{l}\text { One teacher (university education) } \\
\text { +two caregivers (secondary educa- } \\
\text { tion and carer's course) }\end{array}$ & $\begin{array}{l}4500 \text { Kč } \\
\text { (funded by EU) }\end{array}$ \\
\hline $\begin{array}{l}\text { Children's } \\
\text { group }\end{array}$ & $\begin{array}{l}\text { Non- } \\
\text {-profit } \\
\text { organiza- } \\
\text { tion }\end{array}$ & $\begin{array}{l}20 \text { children, } \\
1-7 \text { years }\end{array}$ & $\begin{array}{l}\text { One teacher (university education) } \\
\text { + two caregivers (secondary or uni- } \\
\text { versity education in another field } \\
\text { and carer's course) }\end{array}$ & $\begin{array}{l}6800 \mathrm{Kč} \\
\text { (funded by EU) }\end{array}$ \\
\hline $\begin{array}{l}\text { Children's } \\
\text { centre }\end{array}$ & $\begin{array}{l}\text { Private } \\
\text { individual }\end{array}$ & $\begin{array}{l}10 \text { children, } \\
1-4 \text { years }\end{array}$ & $\begin{array}{l}\text { Two to three caregivers depending } \\
\text { on age (secondary education, } \\
\text { students of education) }\end{array}$ & $\begin{array}{l}720 \mathrm{Kč} \\
\text { (subsidized } \\
\text { by employers) }\end{array}$ \\
\hline
\end{tabular}


Table 2 Characteristics of the respondents

\begin{tabular}{|l|c|c|c|c|c|c|}
\hline Respondent & Age & Profession & $\begin{array}{c}\text { Number } \\
\text { of children }\end{array}$ & $\begin{array}{c}\text { Age } \\
\text { of child }\end{array}$ & Job & Education \\
\hline Mother 1 & 31 & $\begin{array}{c}\text { Sales assistant at } \\
\text { a petrol station }\end{array}$ & 1 & 3 years & $\begin{array}{c}\text { Maternity } \\
\text { leave }\end{array}$ & $\begin{array}{c}\text { Secondary } \\
\text { education }\end{array}$ \\
\hline Mother 2 & 28 & Nurse & 1 & 2.4 years & $\begin{array}{c}\text { Maternity } \\
\text { leave }\end{array}$ & $\begin{array}{c}\text { Carer's } \\
\text { course }\end{array}$ \\
\hline Mother 3 & 43 & Beautician & 1 & 2.8 years & Employed & $\begin{array}{c}\text { Carer's } \\
\text { course }\end{array}$ \\
\hline Mother 4 & 32 & Insurance agent & 2 & 2.9 years & $\begin{array}{c}\text { Maternity } \\
\text { leave }\end{array}$ & $\begin{array}{c}\text { University } \\
\text { education }\end{array}$ \\
\hline Mother 5 & 31 & Nurse & 2 & 2 years & $\begin{array}{c}\text { Maternity } \\
\text { leave }\end{array}$ & $\begin{array}{c}\text { University } \\
\text { education }\end{array}$ \\
\hline Mother 6 & 35 & $\begin{array}{c}\text { Assistant in } \\
\text { construction }\end{array}$ & 1 & 2.3 years & $\begin{array}{c}\text { Maternity } \\
\text { leave }\end{array}$ & $\begin{array}{c}\text { Carer's } \\
\text { course }\end{array}$ \\
\hline Mother 7 & 34 & University teacher & 1 & 2.3 years & $\begin{array}{c}\text { Maternity } \\
\text { leave }\end{array}$ & $\begin{array}{c}\text { University } \\
\text { education }\end{array}$ \\
\hline Mother 8 & 38 & University teacher & 3 & 2.6 years & Employed & $\begin{array}{c}\text { University } \\
\text { education }\end{array}$ \\
\hline Mother 9 & 28 & University teacher & 1 & 1 year & $\begin{array}{c}\text { Maternity } \\
\text { leave }\end{array}$ & $\begin{array}{c}\text { University } \\
\text { education }\end{array}$ \\
\hline mother 10 & 37 & Lawyer & 2 & 2.6 years & Employed & $\begin{array}{c}\text { University } \\
\text { education }\end{array}$ \\
\hline Mother 11 & 34 & Analyst & 1 & 2 years & Employed & $\begin{array}{c}\text { University } \\
\text { education }\end{array}$ \\
\hline Mother 12 & 32 & Laboratory \\
assistant & 1 & 1.6 years & $\begin{array}{c}\text { Maternity } \\
\text { leave }\end{array}$ & $\begin{array}{l}\text { University } \\
\text { education }\end{array}$ \\
\hline
\end{tabular}

The method of semi-structured interviews was chosen for the data collection. The interviews lasted for 30-60 minutes. The interviews were transcribed and coded using the open coding method (Denzin \& Lincoln, 2008) in the Atlas.ti program. To increase the validity, the categorical system was verified by two researchers on $20 \%$ of the data obtained. After the disputed cases had been discussed and $86 \%$ agreement reached, the categorical system was modified. The categories (Table 3) are not disjunct, as the mothers had the opportunity to express themselves freely on some issues, which provided a more comprehensive view of the issues being examined. During the analysis, units of thought were identified, i.e. those parts of the texts that expressed one consistent and clearly definable idea. We call these quotations (442), which were subsequently divided into 13 categories (Table 3). 
Table 3 Category system

\begin{tabular}{|c|c|c|c|}
\hline Category & Subcategory & Category description & Example of a statement \\
\hline \multirow{3}{*}{ 幽 } & $\begin{array}{l}\text { Economic } \\
\text { beliefs }\end{array}$ & $\begin{array}{l}\text { Statements related to finances } \\
\text { provided by the state, the } \\
\text { possibility of working, for example, } \\
\text { part-time, and the issue of the } \\
\text { financial affordability of the facility }\end{array}$ & $\begin{array}{l}\text { I know a lot of girls who just have } \\
\text { a child and then quickly go to } \\
\text { work; they maybe work in a part- } \\
\text { time job for about ten hours a week. }\end{array}$ \\
\hline & $\begin{array}{l}\text { Beliefs about } \\
\text { a child }\end{array}$ & $\begin{array}{l}\text { Statements related to the specific } \\
\text { features of the child entering or } \\
\text { attending the facility. }\end{array}$ & $\begin{array}{l}\text { I don't think he was a loner and he's } \\
\text { still not. }\end{array}$ \\
\hline & $\begin{array}{l}\text { Socially } \\
\text { influenced } \\
\text { beliefs }\end{array}$ & $\begin{array}{l}\text { Statements related to the } \\
\text { formation of beliefs by society, } \\
\text { family, acquaintances, experts, or } \\
\text { reading. }\end{array}$ & $\begin{array}{l}\text { My mother-in-law always tells me } \\
\text { that in their time, she had to put } \\
\text { my husband in kindergarten from } \\
\text { a very young age. And I should } \\
\text { never make such a mistake; she } \\
\text { didn't have time to enjoy being with } \\
\text { her child at all. }\end{array}$ \\
\hline \multirow{4}{*}{.0ّ } & $\begin{array}{l}\text { Ease of } \\
\text { access to the } \\
\text { facility }\end{array}$ & $\begin{array}{l}\text { Statements related to the criteria } \\
\text { for selecting a facility because of } \\
\text { ease of access for a family member. }\end{array}$ & $\begin{array}{l}\text { The fact that Grandma lives close } \\
\text { to the facility, about ten minutes } \\
\text { on foot. }\end{array}$ \\
\hline & $\begin{array}{l}\text { Character- } \\
\text { istics of the } \\
\text { facility }\end{array}$ & $\begin{array}{l}\text { Statements related to the } \\
\text { characteristics of the facility. }\end{array}$ & $\begin{array}{l}\text { There are two caregivers and one } \\
\text { teacher... and there are fewer } \\
\text { children. }\end{array}$ \\
\hline & $\begin{array}{l}\text { Facility } \\
\text { authority }\end{array}$ & $\begin{array}{l}\text { Statements related to the type of } \\
\text { establishment }\end{array}$ & $\begin{array}{l}\text { Well, we were looking at a private } \\
\text { facility with English..., but } \\
\text { in the end we chose a normal } \\
\text { kindergarten. }\end{array}$ \\
\hline & $\begin{array}{l}\text { Negative } \\
\text { expectations }\end{array}$ & $\begin{array}{l}\text { Statements associated with } \\
\text { negative expectations about the } \\
\text { child's attendance at the facility }\end{array}$ & $\begin{array}{l}\text { Illnesses; the first year the children } \\
\text { are always ill. }\end{array}$ \\
\hline
\end{tabular}

\section{Results}

We structure the results of the analysis on the basis of the partial research questions: (1) What are the beliefs of the mothers about services for children under three years of age? (2) What are the mothers' expectations of these facilities? (3) What are the mothers' reasons for searching for these facilities? (4) What are the mothers' experiences with the facilities?

\section{Beliefs of mothers}

The mothers' beliefs about the facilities for children under the age of three 
Table 3 Category system - continuation

\begin{tabular}{|c|c|c|c|}
\hline \multirow{3}{*}{ 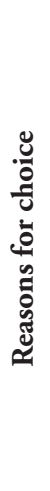 } & $\begin{array}{l}\text { Personal } \\
\text { reasons for } \\
\text { using the } \\
\text { facility }\end{array}$ & $\begin{array}{l}\text { Statements related to the personal } \\
\text { reasons of mothers for using these } \\
\text { facilities. }\end{array}$ & I thought we could both have a rest. \\
\hline & Work duties & $\begin{array}{l}\text { Statements related to the working } \\
\text { reasons of mothers for the use of } \\
\text { these facilities. }\end{array}$ & $\begin{array}{l}\text {... To adapt slowly so that it is not } \\
\text { so stressful; when I go back to work, } \\
\text { you will have to be in kindergarten } \\
\text { all day. }\end{array}$ \\
\hline & $\begin{array}{l}\text { Needs and } \\
\text { character- } \\
\text { istics of the } \\
\text { child }\end{array}$ & $\begin{array}{l}\text { Statements associated with the } \\
\text { reasons for the child's attendance } \\
\text { at the facility and the child's needs } \\
\text { and individual characteristics. }\end{array}$ & $\begin{array}{l}\text {.. To be in a group with children, } \\
\text { so as not to grow up only among } \\
\text { adults. }\end{array}$ \\
\hline \multirow{3}{*}{ 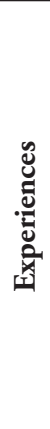 } & $\begin{array}{l}\text { Adaptive } \\
\text { reactions of } \\
\text { the child }\end{array}$ & $\begin{array}{l}\text { Statements related to the } \\
\text { experience with the adaptation of } \\
\text { the respondents' children. }\end{array}$ & $\begin{array}{l}\text { From the beginning, he always } \\
\text { cried from the start, always in the } \\
\text { morning. }\end{array}$ \\
\hline & $\begin{array}{l}\text { Benefits of } \\
\text { attendance }\end{array}$ & $\begin{array}{l}\text { Statements showing the benefits } \\
\text { of the child attending the facility. }\end{array}$ & $\begin{array}{l}\text { Then I saw that when I met my } \\
\text { friends, he played with their } \\
\text { children more; he used to be glued } \\
\text { to me and would just sit on my lap. }\end{array}$ \\
\hline & $\begin{array}{l}\text { Charac- } \\
\text { teristics of } \\
\text { a teacher }\end{array}$ & $\begin{array}{l}\text { Statements related to the } \\
\text { experiences of mothers and the } \\
\text { characteristics of teachers and } \\
\text { their actions and behaviour. }\end{array}$ & $\begin{array}{l}\text { Don't cry, Lukás, mummy is } \\
\text { coming. They stroked him, they gave } \\
\text { him a motorcycle, they really looked } \\
\text { after him well. }\end{array}$ \\
\hline
\end{tabular}

contain three subcategories: economic beliefs, beliefs about the child, and socially influenced beliefs, which are often associated with different stereotypes or influenced by the respondents' environment.

The statements identified in the subcategory economic beliefs concerned dissatisfaction with the amount of state financial support during maternity leave and were expressed mainly by respondents with secondary education: If you have maternity leave for three and a halfyears, then sorry, but if you have a mortgage and loads of other things, you basically get nothing, or for those four years, to get 3400 Czech crowns, who can live on that? (mother 1)

Some statements pointed to the possibility of choosing short-term jobs or an earlier return to work. We noted these statements among mothers with higher education: I got a job offer to teach here as an external teacher and because my husband works here. I was on maternity leave, but I wanted to try it... Now I have to say in retrospect that it's good. That the child... if it is not eight hours every day, he gradually gets used to it (mother 8). 
We also saw a belief that returning to part-time work may not pay off for mothers: That's why I'm not at work, because it's not worth it if you want to go to work and have a second child and I would just have a quarter of a salary, and if someone is in work, their maternity leave is calculated from that small salary. So it's easier for me to be at home and basically take care of the household. (mother 2)

Some of the statements concerned the finances associated with placing a child in institutions for children under the age of three: I think everyone should receive some financial support, but some people are at home with their children and they have the same opportunity to put their children into kindergarten as we do. Of course, when it costs a thousand, or three thousand, or five thousand, it depends on your salary and how you decide for yourself. (mother 2)

These statements were also connected with the idea of the state financing families with small children. This means supporting the families of children under the age of three financially, regardless of whether the mothers are employed or not and whether or not they use childcare facilities for children under the age of three. As for the finances associated with the use of these facilities, none of the mothers questioned the need to pay for these services. We noticed a difference in the question regarding how much the fees should be. Mothers from a smaller city said that 2-5 thousand would be acceptable, whereas in a larger city mothers would be willing to pay 6-8 thousand a month: I have no problem with that. I understand that private children's groups are not state institutions and I perceive the fees as the price to pay for an individual approach. (mother 11)

Another subcategory was the belief in the ability of a child to attend institutions for children under three years of age. Opinions often differed on the appropriate age at which to enter these facilities, but also on the number of days spent in them: It depends on each child and their needs. If the mother perceives that the child is not ready for kindergarten, he or she should stay at home. Mothers know the child best. (mother 10)

The third subcategory points to the influences of the environment (society, family, acquaintances, experts, reading articles). These beliefs relate in particular to the decision on whether to entrust the child to institutional care. The most common reason is the mother's right to continue working, but on the other hand, there were also statements related to a warning that institutional care is harmful to children and that it is healthy for the child to grow up in the care of the mother. Sometimes there were expressive opinions saying that a mother who entrusts her child to an institution is a bad mother: My mother-in-law always tells me that in their time, she had to put my husband in kindergarten from a very young age. And I should never make such a mistake; she didn't have time to enjoy being with her child at all (mother 2). Well, I was scared, as I didn't know; I read some articles about the fact that it could have some consequences for the child, that there could be some trauma. (mother 8) 
Some also expressed the opinion that it was good for a child to meet peers: As young people, not my category at all, they just appreciated it, so it's great to put a child in kindergarten. (mother 5) I asked the psychologist what she thought about it and said that once a week it was okay for such a small child, the four hours she was there for, that it couldn't hurt. (mother 7)

\section{Expectations of mothers}

Four subcategories were identified in the category of maternal expectations. The mothers most often mentioned the ease of access of the facility, the funding body of the facility, the quality of the facility, and negative expectations.

The ease of access of the facility was mentioned by mothers in relation to the family members who would most often take the child to the facility or pick the child up: The fact that Grandma lives close to the facility, about ten minutes on foot. (mother 6) ... excellent kindergarten, and it's really close to our house. (mother 2)

The second subcategory, the funding body of the facility, shows two opposing tendencies of mothers: trust or distrust in state institutions. Some mothers said that they prefer state facilities, while some said they were in favour of private facilities: Well, we also considered a private one, but we didn't think about it that much, because they chose us right away, so I would have thought about it if they hadn't. (Mother 6) Those who considered private facilities expected that teachers would have a more respectful approach towards children: I knew right away that I did not want my daughter to go to a state kindergarten. (mother 11)

The third subcategory linked the expectations of the mothers with the schools' positive characteristics. Most often, the mothers mentioned the individual and kind approach of the teachers, the smaller number of children in the class, and the ratio of children to teachers: Well, we especially liked the fact that in addition to the teachers, there are also the caregivers, that there are more of them per child, and the smaller number of children in each class, and then we liked the environment, the classroom... (mother 5) Furthermore, the mothers mentioned that they expected better equipment and a full programme for children: Maybe once a month they had a white day and a red day... (mother 6 ). There were also expectations associated with informing mothers through websites or a bulletin board.

The last subcategory describes the negative expectations of the mothers, which we can also call concerns. The first is the fear of trauma which might arise from the child's early entry into the institution, from being looked after by someone other than the mother: When my daughter was crying so much, I was afraid that she would have some trauma. (Mother 9) Another concern that mothers often expressed was children often being ill within a group: That's right, someone in the group just sneezes, and the child catches something. (mother 2) 


\section{Reasons for a child starting at a facility}

The category of reasons for the child's entry into a facility for children under three years of age is characterized by three subcategories: personal reasons, job opportunities, and the needs and characteristics of the child.

Some of the personal reasons why families look for these facilities include, for example, the mothers' need to focus more on the household, caring for another child, or the need to rest more: I can tidy up at home and so it was also for my personal reasons. (mother 5) Probably when my son was born, when he was half a year old, we thought that she was missing being with children, as we only went out with her a bit and it was like we stopped paying attention to her so much as she was the older one. (mother 4)

In other cases, the mothers' decision to have a child affects the mother's job opportunities: It was purely because of work, because I was actually employed, I have some projects here, and I don't really have a babysitter, not even a granny. So actually mainly so I can go to the office here for at least two or three hours. So purely work reasons. (mother 9)

For mothers with secondary education, one of the reasons for placing a child in a facility was preparation/adaptation for the mother's return to full-time employment. At the same time, these mothers expected complications in adaptation, so by placing the child in the facility sooner they were giving some time for them to get used to the facility and have the opportunity to deal with difficulties with adapta- tion in advance: ... To adapt slowly so that it is not so stressful; when I go back to work, you will have to be in kindergarten all day... (mother 3)

The last subcategory of reasons for a child's entry into a facility for children under three years of age is the child's needs and individual characteristics. The mothers often described the need for children to have a varied and appropriate programme. They also expressed their own limits, which do not allow for children's all-round development (e.g. cutting things out of paper with scissors) because of fear for their safety. They also mentioned the need for social contact with children of the same age. Other reasons were also excessive fixation of the child on the mother, the child's fear of interactions with children of the same age, hyperactive behaviour on the part of the child, and physical limitations. The vast majority of the mothers assumed that institutional facilities would help their children overcome or deal with these individual characteristics: We chose this because my son was overly attached to me and he was quite often ill and the doctor recommended, if we wanted to put him in kindergarten, to let him get away from me a bit, because he was so scared, he was terribly afraid of people; he was always just stuck to me, so that's why she recommended it. (mother 6)

\section{Mothers' experience}

The category of maternal experience is characterized by three subcategories: reaction to the child's adaptation, benefits of attendance, and teacher characteristics. 
In terms of adaptation, all the mothers expressed previous experience with their children being looked after (by the child's father, grandmother, uncle or aunt, or an acquaintance), which, according to the mothers, had a positive effect on the child's entry into the institution. The adaptive response of children to attending a facility for children under the age of three was varied. In all facilities, the adaptation process was gradual. First the mothers came with the child, then the children came by themselves for one or two hours, then for the morning, and finally for the whole day. The children's reactions to adaptation were often characterized by crying, which lasted for a different length of time for each child (crying for one day to crying every morning for half a year): At first he always cried right from the beginning, always in the morning. (mother 3) Sometimes the child cried during changes in activities (preparation for going out, coming in from outside, etc.): October was better; the teacher told me that he still cried, but just because they were supposed to go out and they had to get changed, because he liked an activity, and when he had to interrupt it, he wanted to play and he suddenly had to go out. But then he is already happy outside, and as they go inside again, he cries again; it's during those changes of state. (Mother 5) Most mothers described the adaptation as being over within two months.

Some mothers expressed their experience with children's empathy, i.e. the transferral of crying from one child to another. They often realized that soon af- ter they left, the child would calm down. They also reported the experience that some children cried even after their arrival: When I took her there she cried but she also cried when I came ... She only cried for a while; when we left to get in the car, she was fine again, then she mostly fell asleep because I only took her there in the morning, I transferred her to her bed at home and she was fine. (mother 8)

An important indicator of the course and management of adaptation is the child's behaviour, from the initial refusal to attend to looking forward to it: He usually didn't want to in the morning; he said he didn't want to go, so he was sometimes just silent and then of course it got better over time, then he took everything with him, he was already happy there. (mother 9)

The benefits of the child's attendance were seen by mothers mainly in the socialization of children. At first, the children built a relationship with the teacher, whom they often perceive as a surrogate caregiver: When I was walking by outside, I looked in to see how he was getting on, like everyone can say he's fine, but that's their opinion, and I saw him sitting by the teacher and she was really stroking him, the teachers are so wonderful. (mother 1) Another commonly mentioned benefit is the establishment of a relationship with other children and also the development of children's play: Otherwise, such as for friends, she has already made some friends here; she talks about some of them. (mother 4) Then I saw that when I met my friends, he played with their children more; he used to be glued to me and would just sit on my lap. (mother 5) 
A significant benefit of attendance was mentioned by mothers as children's skills being developed, such as speech, motor skills, independence in activities where they have to help themselves, hygiene habits being strengthened, and inspiration in playing: She is more open, there are more stimuli, she has a bigger vocabulary, she plays more games, more like, she is really interested when they have some activities in the kindergarten, I mean, for example, they had some hunters, so the whole family found out that in the forest when we come across a deer, we shouldn't pet it, and when we come across a fox, it might have rabies and an angry fox gets wound up. (mother 3 )

The last benefit of the child's attendance at the facility to be mentioned is the adoption of the routine of the facility and a certain order. Mothers expressed the positive effects of this internalization of children on the stabilization of the family routine.

The last subcategory describing the mothers' experiences is the characteristics of the teacher. The communicative competencies of the teacher proved to be crucial. Mothers appreciate receiving feedback about the child and his or her behaviour in the facility. Often, this feedback was a significant factor during adaptation. In the process of adaptation, the mothers accepted the teacher's guidance, her suggestions on how to continue, and her reassurance. Mothers often expressed their confusion about the child's crying and the difficulty in dealing with the situation for themselves: There was a turning point at the end of September, when the teacher said that we should leave him until twelve o'clock, that it was fine. (mother 2)

Another characteristic of a teacher is the teacher's approach to the child: her sensitivity, individual and respectful approach, and knowledge of the child's interests. The mothers often mention the importance of hugging a child or offering a toy s/he likes: Don't cry, Lukás, mummy is coming. They stroked him, they gave him a motorcycle, they really looked after him well. (mother 5)

\section{DisCUSSION AND CONCLUSION}

In this text, we have focused on the views of mothers relating to the care and education of children under three years of age against the background of the international context. Despite its limitations because of the small sample, the study gave us at least a partial insight into the thinking of Czech mothers about the care of children under the age of three.

Although the Czech Republic is one of the countries with extremely low use of childcare services for children under three years of age, at least in large cities these services can be used by both mothers on maternity leave and employed mothers. However, in the sample that was examined we can see a predominant number of mothers with a university degree who use these services and who are also employed (which may also be a limitation of this study). These findings are in line with the findings of e.g. Kuchařová et al. (2006a, 2009). Despite the availability of these facilities in larger cities, moth- 
ers point to some shortcomings of the system, especially the relative lack of opportunities for mothers to work part-time and the unfavourable calculation of state financial support for a second maternity leave if they are working shorter hours. On the other hand, mothers appreciate the tax relief on the fees for these services. We noticed small differences in the statements of the respondents in the economic aspects regarding the use of childcare facilities for children under three years of age. Respondents with lower (secondary) education place greater demands on the state and its financial interventions.

The mothers' expectations associated with the characteristics of the facility indicate an effort to create a good environment for the development of their children (fewer children per teacher, an individual approach by the teacher, and a good programme). Similar results were obtained by the study of Gamble, Erwing, and Wilhelm (2009), who found that the curriculum, daily routine, being childcentred, and the development of school readiness are important for mothers. The competence of the teacher in facilities for children under three years of age is one of the key elements of quality and it thus speaks for the requirement of having an appropriate qualification, something which is currently unsatisfactory in the Czech Republic (Syslová, Borkovcová, \& Průcha, 2014, p. 181). With regard to the requirements of the state, the teachers in the facilities that were examined had above-standard education and also, thanks to the financial support provided by the EU, the teacher-to-child ratio was reported to fit their requirements, i.e. it was lower than expected by the state.

Regarding mothers' choice from the point of view of the funding bodies of facilities for children under three years of age, in this respect, our respondents do not deviate in any way from the attitudes of mothers towards private and state facilities on an international scale. In our research, the mothers were divided into two groups, some leaning towards state care and, despite using private care, they move their children to state institutions as soon as possible, and the other group looking for alternatives and staying with them, despite the possibility of going to state institutions. On the one hand, the role of mothers' education plays a role here, as it affects their economic status, and at the same time it reveals the mothers' expectations that private facilities will have a better approach and better facilities than state institutions. Similar conclusions are drawn from the studies of Gamble, Ewing, and Wilhelm (2009) or Kampichler, Dvořáčková, and Jarkovská (2018). However, this phenomenon is alarming precisely because of the reproduction of social inequalities, as there is a greater opportunity for mothers with a higher social status to have their children segregated in certain institutions. The need and urgency of ensuring the quality of these facilities (e.g. by ensuring a national programme for the whole spectrum of ECEC with clearly defined quality criteria) and their availability to the whole spectrum of society is increasing. 
Our study shows that mothers who have opted for institutional care for their children under the age of three are motivated by completely individual motives, which are usually not only related to economic reasons. A decisive element in their motivation appears to be the needs of the children, which correlates with the results of the Hoem study (2005, p. 570), where the perception of mothers about the quality of these facilities for children under three years of age and to what extent they meet their needs appears to be an important indicator.

There are three groups of mothers, according to the data analysis, applying three different strategies. The first group of mothers is motivated to return to work early; they are university-educated women (three respondents) who work part-time one or two days a week. Their children are from one to two years of age. These mothers expect from institutional care first and foremost a quality caregiver who will take care of a smaller number of children. The second group is formed of mothers overburdened with care (mothers who state that they no longer have the capacity to create a programme and activities appropriate to the age of their children). These are mothers with high school or university education (eight respondents). These mothers use services for children from two to three years of age for several halfdays or whole days. The expectations these mothers have of institutional care are primarily a varied programme and then an open approach to the children on the part of the teacher. The third group consists of two respondents who are looking for these facilities because of the specific individual features of their children (e.g. a heart defect, excessive shyness). These mothers use childcare services for children under three years of age. These are mothers with high school or university education (two respondents). The period these services are used for is dictated by the specific characteristics of the child. They expect a lower number of children in the class, a lower ratio of children per teacher, and a quality educational programme.

While we are trying to find the answer to the main research question: How do mothers perceive facilities for children under three?, the research has shown a relatively positive perception of services for very young children. The experience of mothers across three different facilities shows the positive characteristics of the female caregivers, especially in the field of communication skills, which are very important professional skills for people caring for children under three years of age (cf. Grůzová \& Syslová, 2015, pp. 54-57). Also, the benefits that the mothers talked about (the child's language development, motor skills, self-care, strengthening of hygiene habits, etc.) are similar to other research conclusions (e.g. Sammons et al., 2008a, 2008b). These benefits are among the key expectations and reasons why mothers choose institutional care for children under three years of age, although in our research sample the primary choice was usually care provided by a close person (most often grandparents). However, care provided by a close person was perceived by the mothers rather as a pre-adaptation to 
separation from the mother and entry into institutional care, which is similar to the results obtained by the studies of Gray (2005) or Hamplová (2014).

At present, it is a minority group of mothers whose perception of institutional care for children under three years of age we have tried to map. Uncovering their experiences contributes to the discussion about the quality of these services in the Czech Republic. Mapping the views of mothers who do not use these services could contribute to a deeper understanding of public opinion on these services. It would also be interesting to follow the opinions of fathers or grandparents, who could bring another important perspec- tive to the view of institutional care for children under three years of age.

The Czech Republic is one of the countries with a lower quality of services for children under three years of age compared to other European Union countries (the differentiated system, the responsibilities of various ministries, the missing curriculum, the low demands on the qualifications of caregivers) (Neyer, 2003; Syslová et al., 2014). The findings of this research, which show a link between teacher qualifications and the benefits of caring for children under the age of three, could also contribute to recommendations for policy decisions on the form and conditions of caring for these children.

\section{References}

Del Boca, D., Pasqua, S., \& Pronzato, C. (2006). The impact of institutions on motherhood and work. ISER Working Paper 2006-55. Colchester: University of Essex.

Denzin, N. K., \& Lincoln, Y. S. (Eds.). (2008). Strategies of qualitative inquiry. 3rd ed. Los Angeles, CA: SAGE.

Duncan, S., Edwards, R., Alldred, P., \& Reynolds, T. (2004). Mothers and childcare: policies, values and theories. Children and Society, 18(4), 245-265.

European Commission (2008). Mothers face shortage of childcare services, says EU report. European Commission News. Available from http://ec.europa.eu

European Commission (2013). Childcare: Commission calls on member states to do more. Available from https://ec.europa.eu

European Commission (2016). Provision of quality early childcare services. Luxembourg: Publications Office of the European Union. Available from https:/ec.europa.eu

European Commission/EACEA/Eurydice (2019). Key data on early childhood education and care in Europe - 2019 edition. Eurydice Report. Luxembourg: Publications Office of the European Union. Available from https://eacea.ec.europa.eu/national-policies

Gamble, W. C., Ewing, A. R., \& Wilhelm, M. S. (2009). Motheral perceptions of characteristics of non-motheral child care: Belief dimensions, family and child correlates. Journal of Child and Family Studies, 18, 70-82.

Gray, A. (2005). The Changing Availibility of Grandmothers as Caregivers and Its Implications for Childcare policy in the UK. Journal of Social Policy, 34(4), 557-577. 
Grůzová, L., \& Syslová, Z. (2015) A two-year-old child in preschool education. Brno: Masaryk University.

Hamplová, D. (2014). Hlídání vnoučat českými prarodiči v mezinárodním srovnání [Taking care of grandchildren: An international comparison]. Data a výzkum - SDA Info, 8(1), $25-40$.

Hašková, H., Mudrák, J., \& Saxonberg, S. (2013). Péče o nejmenši: Boření mýtů [Caring for the little ones: Debunking myths]. Praha: SLON.

Hašková, H., \& Uhde, Z. (Eds.). (2009). Women and social citizenship in Czech society: Continuity and change. Praha: Academy of Sciences of the Czech Republic.

Hoem, J. M. (2005). Why does Sweden have such high fertility? Demographic Research, 13(22), 559-572.

Höhne, S., \& Kuchařová, V. (2016). Rodinná politika a formální a neformální péče o předškolní děti ve vybraných státech Evropy [Family policy and formal and informal care for preschool-age children in selected European countries]. Politická ekonomie 64(7): 867-890.

Kaga, Y., Bennett, J., \& Moss, P. (2010). Caring and learning together: A cross-national study on the integration of early childhood care and education within education. Paris: UNESCO.

Kameraman, S. B., Neuman, M., Waldfogel, J., \& Brooks-Gunn, J. (2003). Social policies, family types and child outcomes in selected OECD countries. OECD Social, Employment and Migration Working Papers No. 6.

Kampichler, M., \& Kispéter, E. (2014). Public maternalism in the Czech Republic and Hungary: Work-family policies in two post-socialist welfare states. socio.hu, 2, 77-92.

Kampichler, M., Dvořáčková, J., \& Jarkovská, L. (2018). Choosing the right kindergarten: Mothers' reasoning about their ECEC choices in the context of the diversification of ECEC programs. Journal of Pedagogy, 9(2), 1-28.

Kuchařová, V., Ettlerová, S., Nešporová, O., \& Svobodová, K. (2006a). Zaměstnání a péče o malé děti z perspektivy rodičů a zaměstnavatelů [Employment and child care from the perspective of parents and employers]. In Š. Jurajda, V. Kuchařová \& K. Machovcová et al. Kariéra, rodina, rovné príležitosti [Career, family, equal opportunities] (pp. 7-12). Praha: Gender Studies.

Kuchařová, V., \& Svobodová, K. (2006b). Sitzzařizeni denní péče o dèti prèdškolního věku v ČR [Network of day care facilities for preschool children in the Czech Republic]. Praha: VÚPSV.

Kuchařová, V. et al. (2009). Péce o děti prèšskolního a raného školního věku [Day care for children of pre-school and early school age]. Praha: VÚPSV.

Kuchařová, V., et al. (2010). Rodina a zamèstnánís obledem na rodinný cyklus [Family and employment with respect to the family cycle]. Praha: VÚPSV.

Kuchařová, V., \& Nešporová, O. (2019). Rodinná politika a formální a neformální péče o předškolní děti ve vybraných státech Evropy [Family Policy and Formal and Informal Care for Preschool-Age Children in Selected European Countries]. Sociologický časopis / Czech Sociological Review, 55(4), 473-501. 
Neyer, G. (2003). Family policies and low fertility in Western Europe. Rostock: Max Planck Institute for Demographic Research.

OECD (2011). PISA in focus 2011/1: Does participation in pre-primary education translate into better learning outcomes at school? Paris: OECD.

OECD (2018a). Typology of childcare and early education services. Paris: OECD.

OECD (2018b). Informal childcare arrangements. Paris: OECD.

OECD (2019). Public spending on childcare and early education. Family Database. Paris: OECD.

Sammons, P., Sylva, K., Melhuish, E., Siraj-Blatchford, I., Taggart, B., \& Hunt, S. (2008a). Effective Pre-school and Primary Education 3-11 Project (EPPE 3-11): Influences on children's attainment and progress in key stage 2: Academic outcomes in year 6 . Research Report No. DCSF-RR048. Nottingham: DCSF Publications.

Sammons, P., Sylva, K., Melhuish, E., Siraj-Blatchford, I., Taggart, B., \& Jelicic, H. (2008b). Effective Pre-school and Primary Education 3-11 Project (EPPE 3-11): Influences on children's development and progress in key stage 2: Social-behavioural outcomes in year 6. Research Report No. DCSF-RR049. Nottingham: DCSF Publications.

Saxonberg, S. (2014). Gendering family policies in post-communist Europe: A historicalinstitutional analysis. Basingstoke: Palgrave.

Saxonberg, S., Hašková, H., \& Mudrák, J. (2012). The development of Czech childcare policies. Praha: SLON.

Sylva, K., Melhuish, E., Sammons, P., Suraj-Blatchford, I., \& Taggart, B. (2004). The effective provision of preschool education (EPPE) project: Final report. Nottingham: DfES Publications.

Syslová, Z., Borkovcová, I., \& Průcha, J. (2014). Péče a vzdělávání dètí v raném věku [Care and education of children at an early age]. Praha: Wolters Kluwer.

Yoshikawa, H., Weiland, C., Brooks-Gunn, J., Burchinal, M., Espinosa, L., Gormley, W. T., ... Zaslow, M. (2013). Investing in our future: The evidence base on preschool education. Washington: Society for Research in Child Development.

\section{Lucie Grüzová}

Department of Primary Education, Faculty of Education, Masaryk University in Brno, Czech Republic; e-mail: gruzova@ped.muni.cz

Zora Syslová

Department of primary education, Faculty of Education, Masaryk University in Brno, Czech Republic 


\section{GRŮZOVÁ, L., SYSLOVÁ, Z. Péče o děti do tř́ let pohledem matek na po- zadí mezinárodního kontextu}

Predložená studie prinášsi do odborného diskurzu pohled na institucionální péči a vzdélávání dètí do tři let. Autorky v úvodu príbližuji kontext péce o déti ve věku do tř̀ let v České republice a komparují jej se situaci v zemich Evropské unie. Jádrem príspèvku se stal pohled rodiču na zařizeni pro dèti do tři let v České republice. Kvalitativni sonda odpovidá na otázku "Jak rodiče vnimaji zařizení pro dèti do trú let?". Hloubkové rozhovory odkryly širokou škálu motivũ oslovených matek, které rozhoduji o umistèni ditète do trí let do institucionálni péce. V konečném dưsledku se však podrizují potrébám potomkư. Situace u sledovaného vzorku je v mnoha obledech srovnatelná se zahraničnimi studiemi, přestože situace tèchto služeb v České republice je specifická svým historickým vývojem.

Klíčová slova: péce a vzděláváni dèti do tři let, zarízení péce o dèti do trú let v České republice, rodinná politika, rodiče 